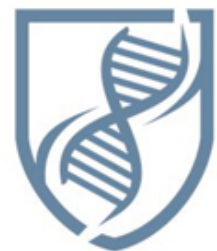

Journal of Bioscience and Applied Research
JBAAR

WWW.JBAAR.ORG

\title{
Preventive effect of melatonin against dimethylbenz(a)anthracene-induced changes in renal tubules of Mice: an Autoradiographic Study
}

\author{
Margit Semmler ${ }^{1}$, Abdel-Baset M. Aref ${ }^{2}$ \\ ${ }^{1}$ Diabetes Research Institute, Düsseldorf University, Düsseldorf, Germany \\ ${ }^{2}$ Zoology Department, Faculty of Science, South Valley University, Qena, Egypt. \\ Corresponding author email: Aref322189@yahoo.com.
}

\begin{abstract}
The present study aims to evaluate the possible preventive effect of melatonin against dimethyl-benz(a)anthracene (DMBA) induced cell proliferation and DNA synthesis in epithelial cells of cortical and medullary renal tubules in mice applying the method of quantitative autoradiography. Exposure to a single injection of DMBA (10mg/ 100g b.w.) and examined after 60 days revealed different changes in cell proliferation in the two portions of the tubules. In males, the mean values raised by $388 \%$ and $363 \%$ for cortical and medullary renal tubules respectively compared to control. The mean grain count over labelled nuclei was reduced $51 \%$ and $35.2 \%$ respectively for the two portions of the renal tubules. In females the cell division was stimulated by $125 \%$ in the cortical tubules and whereas in the medullary portion it remained nearly unchanged compared to control. In males, the mean grain count over labelled nuclei was lower by $47.6 \%$ in cortical renal tubules and by $67.3 \%$ in medullary renal tubules. In females, the mean grain count over labelled nuclei was in both portions reduced by about $60 \%$. Long term exposure to a single injection of DMBA for 120 days increased the cell proliferation in males and females in both portions of the renal tubules. A daily melatonin injection $(100 \mu \mathrm{g} / 100 \mathrm{~g}$ b.w.) for 60 and 120 days proliferation rate by $79.8 \%$ and $83.9 \%$ respectively in males for the two portions, while the mean grain count over labelled nuclei was lower by $20 \%$ and $39 \%$ respectively. In females melatonin attenuated cell proliferation by $67 \%$ and $43 \%$ in cortical and medullary respectively compared to the DMBA exposed group. and reached thereby the level of control. The grain counts over labelled nuclei were reduced identically by $105 \%$ in
\end{abstract}

cortical and medullary renal tubules, but remained still $20 \%$ under that of control.

Keywords: Dimethyl-benz(a)anthracene, Melatonin, Mice, Proliferation, Renal tubules.

\section{Introduction}

Cancer, one of the leading causes of death in the world, occurs due to activation or mutation of oncogenes, or inactivation of suppressor genes. Most of these genes are involved in activation and detoxification of polycyclic aromatic hydrocarbons (PAHs), suggesting the potential role of these compounds in carcinogenesis (Das et al., 2010; Sharma et al., 2012). Polycyclic aromatic hydrocarbons (PAHs), a family of structurally related chemicals, are composed of multiple aromatic rings in which the electrons are delocalized. Sources of PAHs are widely distributed in our environment and form a major class of environmental carcinogens implicated in various types of cancer diseases (Higgins et al., 1961). Human exposure to such components can occur in the workplace, through ambient airborne exposure, in the food supply or through lifestyle exposure such as smoking (Qing et al., 1997). Enzymatic degradation of PAHs leads to generation of highly reactive oxygen species such as peroxides and superoxide anion radicals inducing oxidative stress (Bishayee et al., 2000; Batcioglu et al., 2004). PHA metabolic by-products affect a large range of biological reactions, such as increase in mutation rate, alteration of cellular membrane composition, structural proteins, detoxifying enzymes and cellular signaling proteins (Marnett et al., 2003). The polycyclic aromatic hydrocarbon dimethylbenz(a) anthracene (DMBA), is a potent carcinogene inducing cancer agent in animal models 
in different organs such as in skin (Jayaraj et al., 2011), mammary gland (Currier et al., 2005; Mirunalini et al., 2010; Lin et al., 2012; Wang et al., 2013; El-Bakry et al., 2014), ovaries (Ferreira et al., 2014) and kidneys (Sharma and Paliwal, 2014). Chemoprevention of cancer is a novel and appealing strategy dealing with inhibition, reversal or suppression of carcinogenesis using natural or synthetic agents (Cazzaniga and Bonanni, 2012). The possible mechanism so far reported for the chemopreventive potential include carcinogen detoxification, suppression of genetic mutation, suppression of cell proliferation, induction of apoptosis and modulation of the immune system (Ebeed et al., 2010; Feng et al., 2010; Manoharan and Vasantha, 2012). Various natural products have been evaluated for their anticarcinogenic activity against DMBA induced carcinogenicity such as plant extract of Morinda citrifolia and Moringa oleifera against breast (Mian-Ying et al., 2013) and renal cancer (Sharma and Paliwal, 2014), Clerodendrum serratum against skin carcinogenesis (Chinchali etal .,2011) and nanoparticle-encapsulated curcumin for human cancers (Bisht et al., 2007). Melatonin (N-acetyl-5-methoxytryptamine), a hormone of the pineal gland, has been known to be a chemopreventive agent in in-vivo studies and experimental animal model (Mirunalini et al., 2010; El-Bakry et al., 2014; Ferreira et al., 2014). The present study aims to investigate the effect dimethylbenz(a)antheracene (DMBA) on cell proliferation rate and DNA synthesis in renal epithelial cells of mice after different experimental periods.

\section{Materials and Methods \\ Animals}

Adult Swiss albino mice (60 males and 60 females) aged 90 \pm 2 days and weighing 24-26g were used in this study. All animals were kept under the same conditions of an artificial light-dark cycle $(12 \mathrm{~h}-12 \mathrm{~h})$, temperature $\left(22 \pm 20^{\circ} \mathrm{C}\right)$, and humidity $32 \pm 5$. They were given standard food and water ad libitum.

\section{Chemicals}

9, 10-dimethyl-1, 2-benzanthracene (DMBA) [Sigma Chemical Co., St. Louis, Mo] was dissolved in corn oil at concentration of $50 \mathrm{mg} / \mathrm{ml}$. Melatonin [Sigma Co.] was dissolved in a few drops of absolute ethanol and diluted with distilled water to a concentration of $500 \mu \mathrm{g} / \mathrm{ml}$. Tritiated thymidine, ${ }^{3} \mathrm{H}$-methyl thymidine [New England Nuclear, Boston, Mass.] with a specific activity of $6.7 \mathrm{Ci} /$ mmol served as a radiolabelled tracer. Photoemulsion NTB2 [Estman Kodak, Rochester, New York] in combination with Kodak D-76 developer and Kodak Fixer were used for the preparation of autoradiographs.

\section{Experimental Design}

Two sets of experiments were preformed differing in exposure time to the various chemicals. Both sets of males and females were divided into 3 groups, 10 animals each.

\section{a. Male group}

Short term exposure to DMBA (60 days):

Group C: Control animals were injected subcutaneously with a single injection of corn oil $(0.2 \mathrm{ml} / 100 \mathrm{~g}$ b.w.).

Group D: animals were injected subcutaneously with a single dose of DMBA (10mg/ 100g b.w.) and sacrificed after 60 days.

Group D+M: one day after DMBA application, animals were injected subcutaneously with a daily subcutaneous injection of melatonin $(100 \mu \mathrm{g} / 100 \mathrm{~g}$ b.w.) for 60 days at $4.00 \mathrm{pm}, 2 \mathrm{~h}$ before the end of the light cycle.

Long term exposure to DMBA (120 days)

Group $\mathbf{C}_{\mathbf{A}}$ : Animals of the control group.

Group $\mathbf{D}_{\mathrm{A}}$ : animals were injected subcutaneously with a single dose of DMBA (10mg/ $100 \mathrm{~g}$ b.w.) and sacrificed after 120 days.

Group $\mathbf{D}_{\mathbf{A}}+\mathbf{M}_{\mathbf{A}}$ : animals were injected with DMBA and during the last 30 days additionally injected with melatonin $(100 \mu \mathrm{g} / 100 \mathrm{~g}$ b.w.).

\section{b.females group}

Animals received identical injections of DMBA and melatonin as in male group.

\section{Labelling}

The day after the last melatonin injection, 5 animals of each group were injected subcutaneously with tritiated thymidine (3H-methyl thymidine) at a dose of $1 \mu \mathrm{Ci} / \mathrm{g}$ b.w. and a specific activity of $6.7 \mathrm{Ci} / \mathrm{mmol}$. To minimize any possible diurnal influence, animals were injected at a fixed time $(16.00 \mathrm{~h})$ and sacrificed two hours later by cervical dislocation according to the ethical criteria for animal care and treatment.

\section{Tissues Preparation}

Whole kidneys were removed, dissected, fixed in $10 \%$ neutral formalin and washed in running water to remove unbound $3 \mathrm{H}$-thymidine. Specimens were further processed for paraffin embedding, sectioned at $5 \mathrm{~m}$ and stained with hematoxilin and eosin.

\section{Scoring}

A total of 2,500 labelled and unlabelled epithelial cells of the cortical and medullary renal tubules were scored for each animal and the number of silver grains over labelled nuclei recorded. Cells showing 5 or more silver grains over the nucleus were considered to be labelled in the S-phase of the cell cycle.

${ }^{3} \mathrm{H}$-labelling Index (LI)

The ${ }^{3} \mathrm{H}$-labelling index was expressed as the number of labelled cells per 100 cells:

$$
\text { LI }=\frac{\text { number of labelled cells }}{\text { number of total cells }} \times 100
$$

\section{Mean Grain Count (GC)}

The grain count per labelled nucleus was determined from the number of silver grains over labelled nuclei divided by the total number of labelled cells in the population.

number of silver grains over labelled nuclei

$$
\mathrm{LI}=\frac{\text { number of total labelled cells }}{\mathrm{s}}
$$




\section{Results}

According to the location within the nephron the tubules in the cortex were taken as the cortical portion of renal tubules, while those of the medullary part are regarded as medullary ones. The two portions were considered as two separate populations.

\section{a. Male group}

\section{Short Term Exposure to DMBA}

The number of ${ }^{3} \mathrm{H}$ thymidine labelled epidermal cells and the grains density over labelled nuclei in the cortical portion of renal tubules are given in table 1. Quantitative evaluation of the ${ }^{3} \mathrm{H}$-labelling index in control mice revealed a mean of $0.17 \pm 0.07 \%$. The mean grain count per labelled nucleus was $26.68 \pm 10.36$ (Fig.1). Mice injected with a single dose of DMBA (group D) showed a remarkable increase in the number of labelled cells compared to control (Fig. 2). A mean of $0.83 \pm 0.43 \%$ of all epithelial cells showed an incorporation of ${ }^{3} \mathrm{H}$ thymidine into the nucleus, representing a stimulation of the cell division by $388.2 \%$ compared to control. The grain count per labelled nucleus was reduced by $51.1 \%$ to $13.06 \pm 1.52$ compared to the same group. In animals of group D+M, injected daily with melatonin for 60 days starting one day after exposure to a single dose of DMBA, the number of labelled nuclei was highly reduced compared to the other experimental groups (Fig. 3). Just $0.10 \pm 0.02 \%$ of all cells were labelled. Compared to group $\mathrm{D}$, the cell division was attenuated by $88.0 \%$, while a comparison to control showed $41.2 \%$ lower value. The mean number of grains per labelled nucleus in the group $\mathrm{D}+\mathrm{M}$ was with $13.97 \pm 1.26$ slightly higher than in group D (+7\%), but remained $47.6 \%$ lower than group $\mathrm{C}$.

In the medullary portion of the renal tubules, exposure to DMBA increased the ${ }^{3} \mathrm{H}$ labelling index remarkably by $363 \%$ to $0.37 \pm 0.17$ compared to control. Concomitant exposure to DMBA and melatonin reduced the incorporation rate of ${ }^{3} \mathrm{H}$ thymidine into the DNA by $37.5 \%$ to $0.05 \pm 0.03$ (Table 1 and Figs.4-6). The grain count over labelled nuclei in group $\mathrm{D}$ showed a reduction by $35.2 \%$ to a mean of $14.34 \pm 1.34$. Concomitant exposure to DMBA and melatonin attenuated the value even further to $7.32 \pm$ 4.24. Compared to group D, the value was reduced by $49 \%$ and by $67 \%$ compared to group C (Table 1$)$.

\section{Long Term Exposure to DMBA}

In the cortical portion of the renal tubules, ${ }^{3} \mathrm{H}$-labelling index and the number of grains over labelled nuclei in control animals was identical to those of short term exposure experiments (table2, Fig.7). Mice injected with a single dose of DMBA (group $\mathrm{D}_{\mathrm{A}}$ ) and sacrificed after 120 days of exposure, revealed an extremely high number of ${ }^{3}$ H-labelled cells. $1.19 \pm 0.54 \%$ of all epithelial cells showed an incorporation of the radioactive label. This equals a stimulation of the cell division by $600 \%$ when compared with those of control. The number of grains over labelled nuclei remained constant $(27.16 \pm 4.85 ;+3 \%)$ compared to control (Fig. 8)

In animals of group $\mathrm{D}_{\mathrm{A}}+\mathrm{M}_{\mathrm{A}}$, the cell division rate was attenuated to $0.24 \pm 0.12 \%$.Compared to group $\mathrm{C}_{\mathrm{A}}$, it remained higher by $41.2 \%$. In Contrast to group $\mathrm{D}_{\mathrm{A}}$ it was decreased by $79.8 \%$ (Table 2, Fig.9). The grain count over labelled nuclei of group $\left[\mathrm{D}_{\mathrm{A}}+\mathrm{M}_{\mathrm{A}}\right]$ was decreased having a mean of $21.04 \pm 3.68$. Compared to control and DMBA treated animals the reduction was $22.5 \%$, and $20 \%$ respectively.

In the medullary portion of the renal tubules, long exposure to DMBA increased the ${ }^{3} \mathrm{H}$ labelling index remarkably to $0.56 \pm 0.05$ compared to control $(+600 \%)$. The grain count over labelled nuclei raised by $44.8 \%$ to $31.56 \pm 7.70$ (Table 2). Additional treatment with melatonin attenuated the incorporation rate of ${ }^{3} \mathrm{H}$ thymidine into the cell nuclei remarkably by $839 \%$ to $0.09 \pm 0.05 \%$ compared to the $\mathrm{D}_{\mathrm{A}}$ group: Hereby, the cell division rate was reduced nearly to the level of control. The number of grains over labelled nuclei was decreased to $19.24 \pm 4.16$, a reduction of $39 \%$ compared to group $\mathrm{D}_{\mathrm{A}}$. Compared to group $\mathrm{C}_{\mathrm{A}}$, the mean value was within the range of control (Figs. 10-12)

\section{b. Female group \\ Short Term Exposure to DMBA}

The percentage of labelled epidermal cells and the grains density over labelled nuclei in the cortical portion of renal tubules of female mice are shown in table 3 . In the control group, $0.04 \pm 0.01 \%$ of all epithelial cells were ${ }^{3} \mathrm{H}$ thymidine labelled, while the mean grain count per labelled nucleus was $25.56 \pm 1.05$ (Fig.13).Female mice, injected with a single dose of DMBA and sacrificed after 60 days (group D), showed a remarkable increase in the number of labelled cells compared with that of control mice (Fig.14). The incorporation rate of ${ }^{3} \mathrm{H}$ thymidine was increased by $125 \%$ to $0.09 \pm 0.03 \%$, while the grain count per labelled nucleus was decreased by $60.5 \%$ to $10.14 \pm 1.40$. Animals of group D+M (Fig.15) showed a lower percentage of $3 \mathrm{H}$ thymidine labelled epithelial cells. Just $0.03 \pm 0.001 \%$ showed a labelling. This equals a reduction of $66.7 \%$ compared to group D. A comparison to control revealed that the $3 \mathrm{H}$ labelling index was reduced only slightly ($25 \%$ ) reaching thereby the level of untreated animals. Meanwhile, the grain count was increased to $20.75 \pm 2.16$, being $104.6 \%$ higher than in in group D and just $18.8 \%$ lower than that of control(table 3 ).

In the medullary portion of the renal tubules of the control group, $0.06 \pm 0.02 \%$ of the epithelial cells were ${ }^{3} \mathrm{H}$ thymidine labelled, while the mean grain count reached $30.17 \pm 2.79$ (table 3, Fig. 16). Exposure to a single dose of DMBA showed in this portion of the kidney, in contrast to the cortical portion of the renal tubules, very little effect on the labelling index. Just $0.07 \pm 0.04 \%$ of all epithelial cells were radio-labelled representing an increase by $16.7 \%$. Meanwhile, the grain count was sharply reduced by $61.3 \%$, to $11.67 \pm 1.63$ (Fig. 17). Concomitant exposure to DMBA and melatonin led to a more pronounced increase in cell 
proliferation. Due to this treatment, $0.10 \pm 0.06 \%$ of the cells were ${ }^{3} \mathrm{H}$ thymidine labelled, an increase by $42.9 \%$ compared to group D and by $66.7 \%$ compared to group C. The change in grain count numbers showed similar changes as in the cortical portion of the tubules. $24.04 \pm 1.18$ grains were counted over labeled, an increase by $106 \%$ compared to group D and a reduction of $20.3 \%$ compared to control (Fig.18).

\section{Long Term Exposure to DMBA}

After 120 days, control animals (group $\mathrm{C}_{\mathrm{A}}$ ) showed identical values for both determined parameters. The ${ }^{3} \mathrm{H}$ labelling index was $0.04 \pm 0.01 \%$ and the mean number grains per labelled nucleus $25.18 \pm 1.03$ (table 4 and Fig. 19). Animals injected with a single dose of DMBA (group $\mathrm{D}_{\mathrm{A}}$ ) and sacrificed after 120 days of exposure, revealed an extremely high increase in the number of ${ }^{3} \mathrm{H}$ thymidine labelled cells reaching a percentage of $2.30 \pm 1.06$ cells. This equals a stimulation of cell division by $50 \%$ when compared to control. Meanwhile, the grain count per labelled nucleus dropped to $13.95 \pm 4.52$ or by $44.6 \%$ (Fig. 20). In mice of group $D_{A}+M_{A}$, the cell proliferation rate was attenuated to $0.13 \%$, a reduction by $91 \%$ compared to group D, while compared to control it remained still $425 \%$ higher. The mean grain count over labelled nuclei (13.08 \pm 2.83 ) remained nearly unchanged compared to group $D_{A}$, but stayed $48.1 \%$ lower than that of control (Fig. 21).

In the medullary portion of the renal tubules, a single injection of DMBA increased cell proliferation also highly, but not to such as extend as in the cortical portion of the tubules. The mean value raised to $0.78 \pm 0.13 \%$ resulting in an increase by $1200 \%$ compared to control (table 4, Fig. 23). In contrast to the animals after short term exposure to DMBA, female mice showed aggregations of epithelial cells with ${ }^{3} \mathrm{H}$ thymidine labelled nuclei in some areas of the renal tubules. In the group of mice treated concomitantly with melatonin for the last 30 days of exposure to DMBA, the 3 H-labelling index was reduced to $0.10 \pm 0.06$ representing a reduction by $87.2 \%$ compared to group $\mathrm{D}_{\mathrm{A}}$, while it remained $66.7 \%$ higher than in control (Fig.24). These induced changes were remarkably high, but not as high as in the cortical part of the tubules. The number of grains over labelled nuclei was reduced to $10.93 \pm 0.02$, a reduction of $20.9 \%$ and $63.2 \%$ compared to group $\mathrm{D}_{\mathrm{A}}$ and group $\mathrm{C}_{\mathrm{A}}$ respectively.

\section{Discussion}

The present study investigated the effect of the polycyclic aromatic hydrocarbon dimethylbenz(a)anthracene (DMBA), a possible cancer inducing agent, on kidneys of male mice. To evaluate its inducing effect on cell proliferation and DNA synthesis, experimental animals were injected with a single dose of DMBA (10mg/ $100 \mathrm{~g}$ b.w.) and the incorporation of ${ }^{3} \mathrm{H}$ thymidine into cell nuclei of cortical and medullary portions of renal tubular epithelium was determined quantitatively using light microscopic autoradiography as a technique.
The renal epithelium of adult rats proliferates extremely slowly showing $\mathrm{an}^{3} \mathrm{H}$ thymidine labelling index of the epithelium varying between 0.1 and $0.4 \%$.an (Reiter et al., 1964; Phillips and Leong, 1967). In the present study similar results were obtained. In control mice few epithelial cells nuclei showed an incorporation of the label. However, with the age of experimental animals, the cell proliferation rate varies largely. Weanling rats showed a $5.4 \mathrm{x}$ higher base line of labelling index than that of adult ones, while in old rats (25-months-old) this parameter declines sharply (Reiter et al, 1964; Phillips and Leong, 1967; El-Sokkary et al., 2003)

In the present study, a single injection of DMBA induced a high increase in cell proliferative activity. These results are in agreement with a number of published data (Manoharan and Vasantha, 2012; Agrawal et al., 2010; Mirunalini et al., 2010). Nowadays, it is generally accepted that the xenobiotic agent DMBA induces carcinomas in various organs such as in skin (Jayaraj et al., 2011), in mammary glands (Mirunalini et al., 2010; Lin et al., 2012; Wanget al.,2013; El-Bakry et al., 2014), in ovaries (Ferreira et al., 2014) and in kidneys (Sharma and Paliwal, 2014).

Extending the exposure time to DMBA up to 120 days induced further increase in cell replication. This impact on proliferation activity is quite astonishing, as the kidney possesses most of the common xenobiotic metabolizing enzymes and is able to make an important contribution to the body's metabolism of foreign compounds.

PAHs, like DMBA, are metabolized by a variety of xenobiotic-metabolizing enzymes such as cytochrome $\mathrm{P} 450$ and epoxide hydrolase. These enzymes mainly participate in the conversion of PAHs to more polar and water-soluble metabolites leading to metabolites that are readily excreted from the body. However, during the course of metabolism, a variety of unstable and reactive intermediates of PAHs are formed, and these metabolites seem to attack DNA causing cell toxicity and transformation.

$\mathrm{P} 450$ s and epoxide hydrolase convert PAHs to proximate carcinogenic metabolites. PAH-diols, and these products are then further metabolized by P450s to ultimate carcinogenic metabolites. PAHs are also activated by $\mathrm{P} 450$ and peroxidases to reactive radical cations that bind covalently to DNA. The oxygenated and reactive metabolites of PAHs are usually converted to more polar and detoxified products by phase II enzymes (Shimada and Fujii-Kuriyama, 2004;Baird et al., 2005).

DMBA induces damage in many enzymes involved in DNA repair. In mice kidneys the administration of single dose of $15 \mathrm{mg} / \mathrm{kg}$ b. W. DMBA significantly enhanced the level of xenobiotic enzymes (Sharma and Paliwal, 2014). Furthermore, it enhanced renal malondialdehyde concomitant with a reduction in renal glutathione content, antioxidant enzymes and glutathione-S-transferase. The status of renal aspartate transaminase, alanine transaminase, alkaline phosphatase and total protein content were also found to be decreased along with increase in total cholesterol in DMBA administered mice. 
Table 1: ${ }^{3} \mathrm{H}$-labelling indices and grain counts/labelled nucleus in cortical and medullary portions of renal tubules of male mice after short term exposure (61 days); $\mathrm{C}=$ control, $\quad \mathrm{D}=$ single dose injection of DMBA , $\mathrm{D}+\mathrm{M}=$ single dose injection of DMBA and daily injection of melatonin .

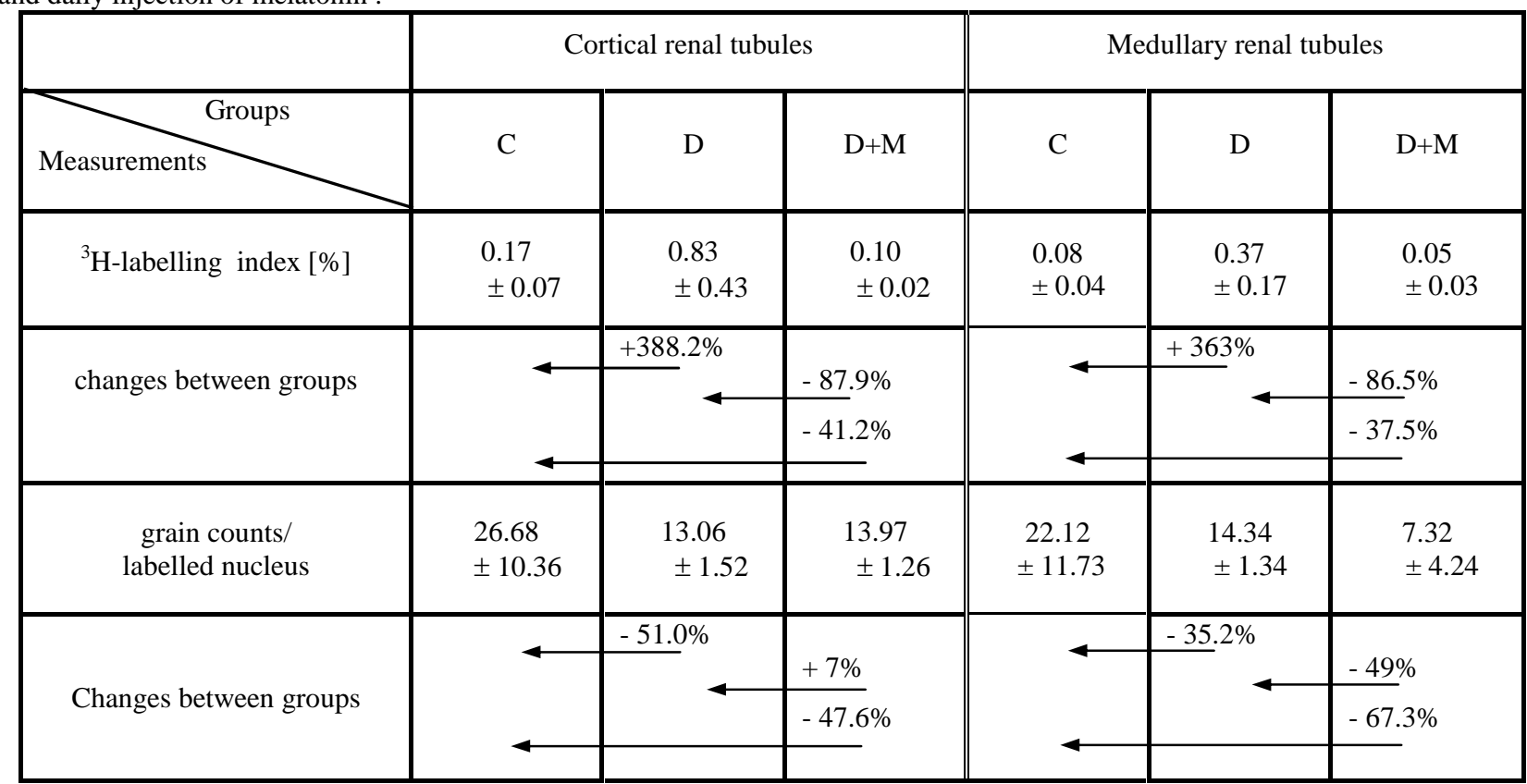

Data are given as mean $\pm \mathrm{SE}$.

Table 2: ${ }^{3} \mathrm{H}$-labelling indices and grain counts/labelled nucleus in cortical and medullary portions of renal tubules of male mice after long term exposure (120 days); $C_{A}=$ control, $\quad D_{A}=$ single dose injection of DMBA; $D_{A}+M_{A}=$ single dose injection of DMBA and daily injection of melatonin

\begin{tabular}{|c|c|c|c|c|c|c|}
\hline & \multicolumn{3}{|c|}{ Cortical renal tubules } & \multicolumn{3}{|c|}{ Medullary renal tubules } \\
\hline Measurements & $\mathrm{C}_{\mathrm{A}}$ & $\mathrm{D}_{\mathrm{A}}$ & $\mathrm{D}_{\mathrm{A}}+\mathrm{M}_{\mathrm{A}}$ & $\mathrm{C}_{\mathrm{A}}$ & $\mathrm{D}_{\mathrm{A}}$ & $\mathrm{D}_{\mathrm{A}}+\mathrm{M}_{\mathrm{A}}$ \\
\hline${ }^{3} \mathrm{H}$-labelling index [\%] & $\begin{array}{l}0.17 \\
\pm 0.07\end{array}$ & $\begin{array}{l}1.19 \\
\pm 0.54\end{array}$ & $\begin{array}{l}0.24 \\
\pm 0.12\end{array}$ & $\begin{array}{l}0.08 \\
\pm 0.05\end{array}$ & $\begin{array}{l}0.56 \\
\pm 0.29\end{array}$ & $\begin{array}{l}0.09 \\
\pm 0.05\end{array}$ \\
\hline changes between groups & & $+600 \%$ & $\begin{array}{l}-79.8 \% \\
+41.2 \%\end{array}$ & & $+600 \%$ & $\begin{array}{l}-83.9 \% \\
+12.5 \%\end{array}$ \\
\hline $\begin{array}{l}\text { grain counts/ } \\
\text { labelled nucleus }\end{array}$ & $\begin{array}{l}26.28 \\
\pm 10.20\end{array}$ & $\begin{array}{l}27.16 \\
\pm 4.85\end{array}$ & $\begin{array}{l}21.04 \\
\pm 3.68\end{array}$ & $\begin{array}{l}21.79 \\
\pm 11.56\end{array}$ & $\begin{array}{l}31.56 \\
\pm 7.70\end{array}$ & $\begin{array}{l}19.24 \\
\pm 4.16\end{array}$ \\
\hline changes between groups & & $+3 \%$ & $\frac{-20 \%}{-22.5 \%}$ & & $+44.8 \%$ & $\frac{-39 \%}{-11.7 \%}$ \\
\hline & & & & & & \\
\hline
\end{tabular}

Data are given as mean \pm SE. 


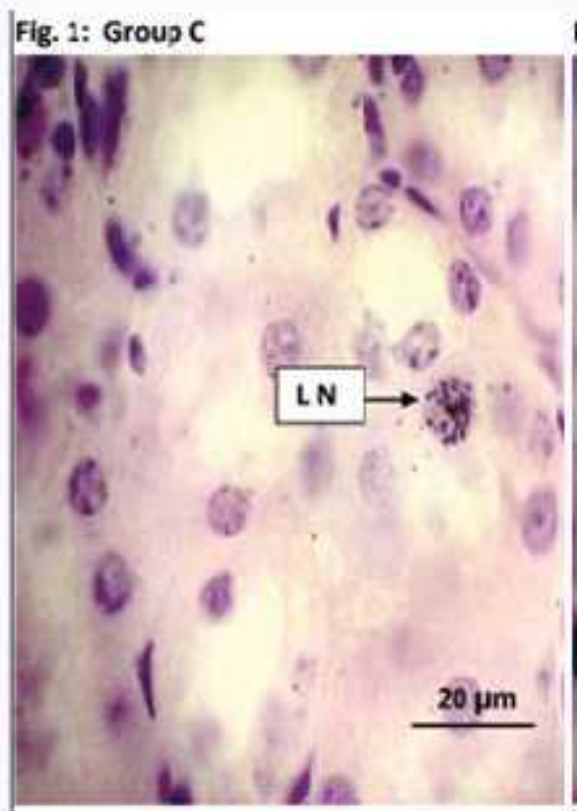

Fig. 2: Group D

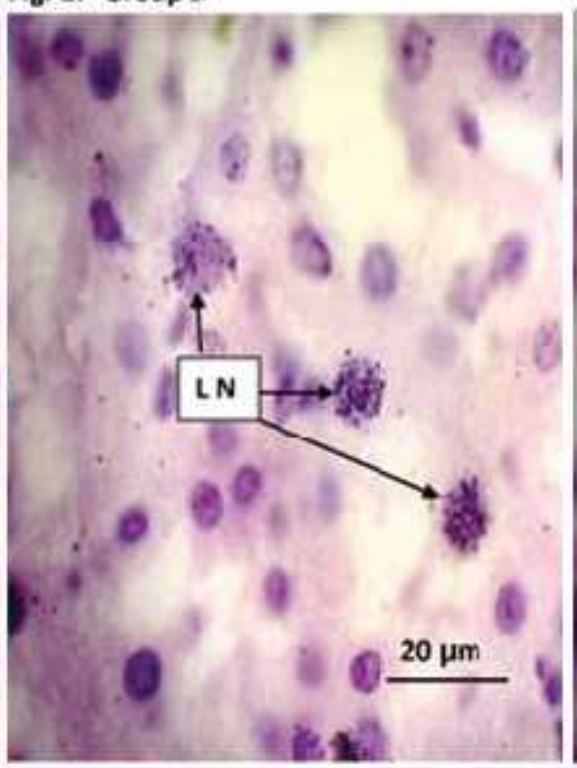

Fig.3: Group D+M

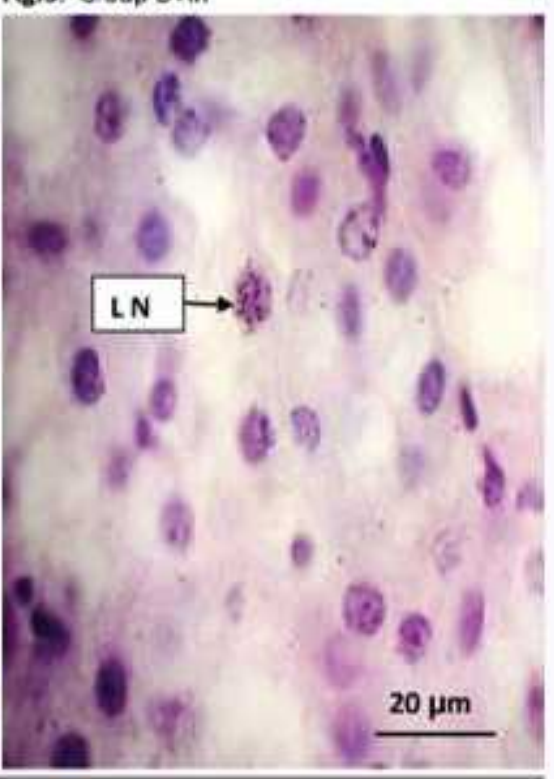

Figs. (1,2,3):Autoradiograms of 'H-thymidine labelled kidney stained with H\&E, showing the distribution of labelied nuclei (LN) in cortical portion of renal tubules of male mice after short term exposure. 1. Control mice (C), 2. Exposed to a single dose $\alpha$ DMBA for 61 days (D) and 3 Exposed to a single dose of DMDA for 61 days and to a daily injection of melatonin for 60 diays

Fig. 4: Group C

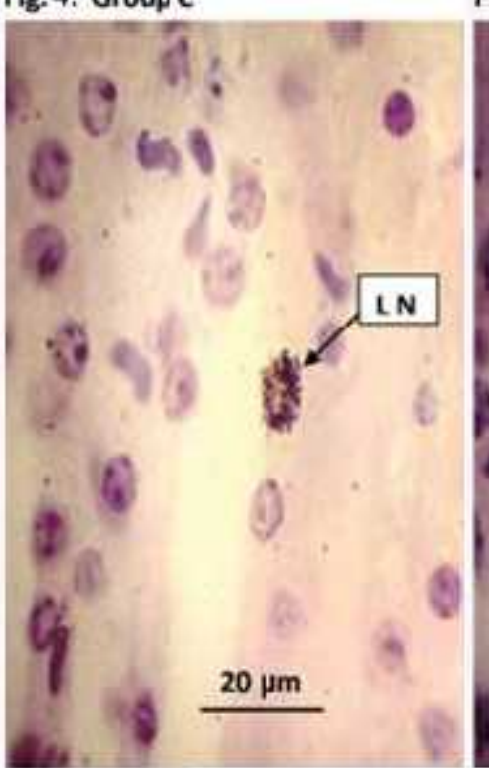

Fig.5: Group D

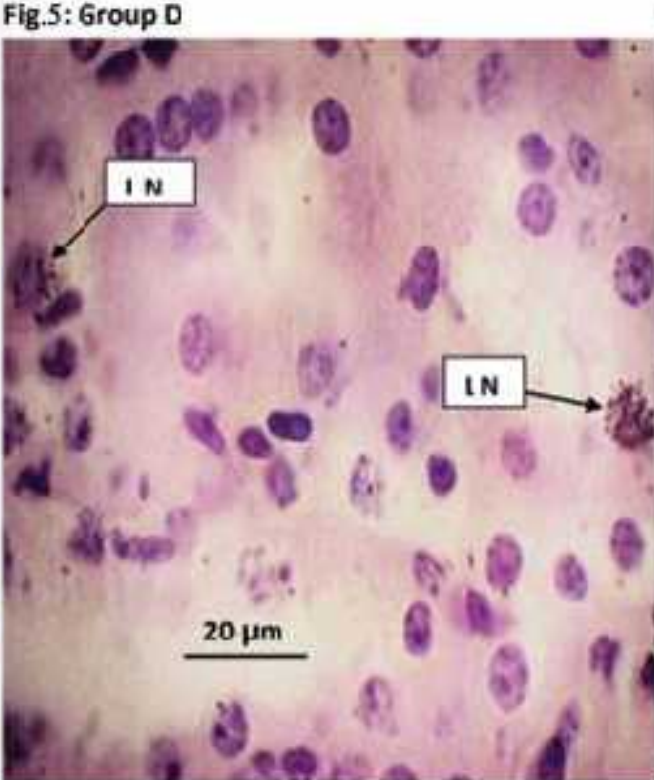

Fig. 6: Group D+M

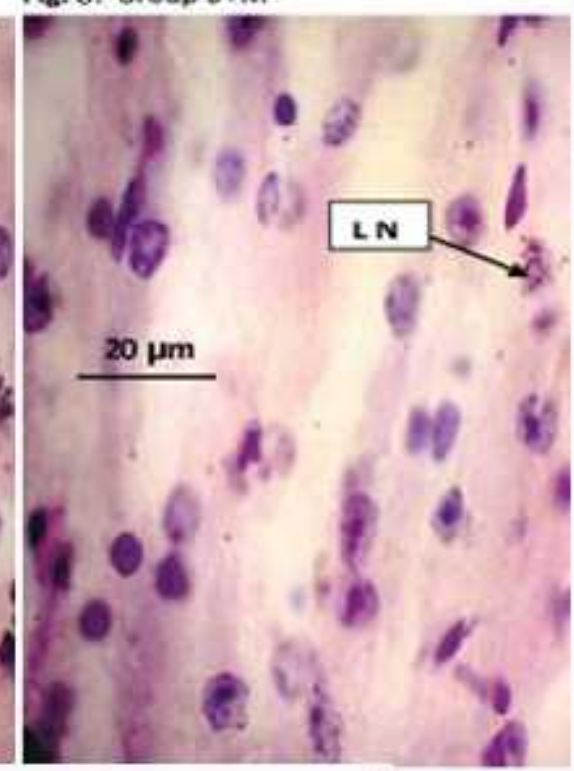

Figs. $(4,5,6)$ :Autoradiograms of ${ }^{3} \mathrm{H}$-thymidine labelled kidney stained with H\&E. showing the distribution of labeled nuclei (LN) in medullary portion of renal tubules of male mice after short term exposure.

4. Control mice (C) 5. Exposed to a single dose of DMBA for 61 days (n) and 6. Fxposed to a single dose of DMBA for 61 days and to a dayily injection ot melatonin for 60 days 
Fig. 7: Group CA

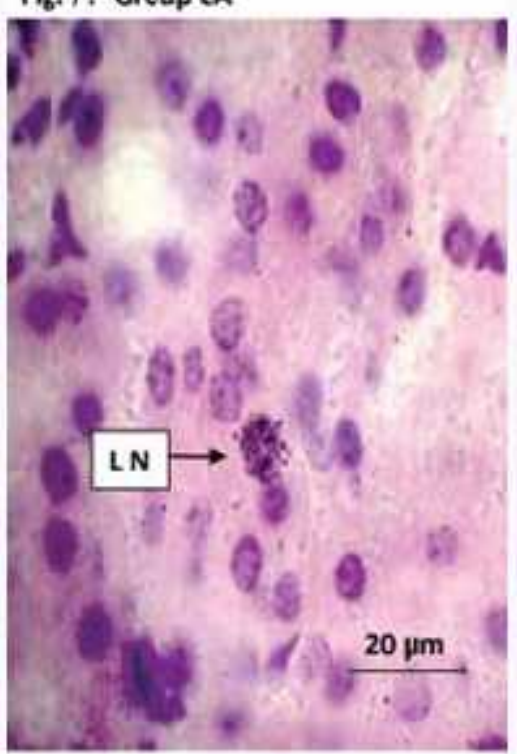

Fig. 8: Group DA

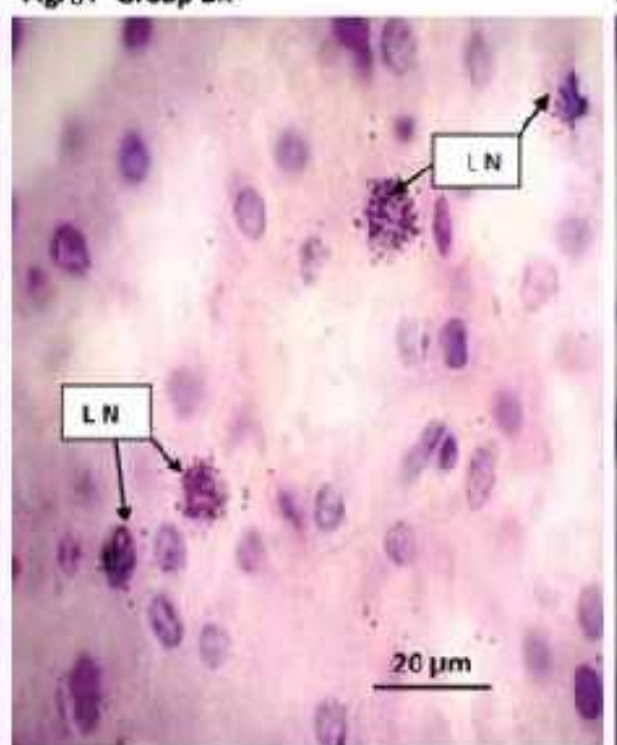

Fig. 9: Group DA+Ma

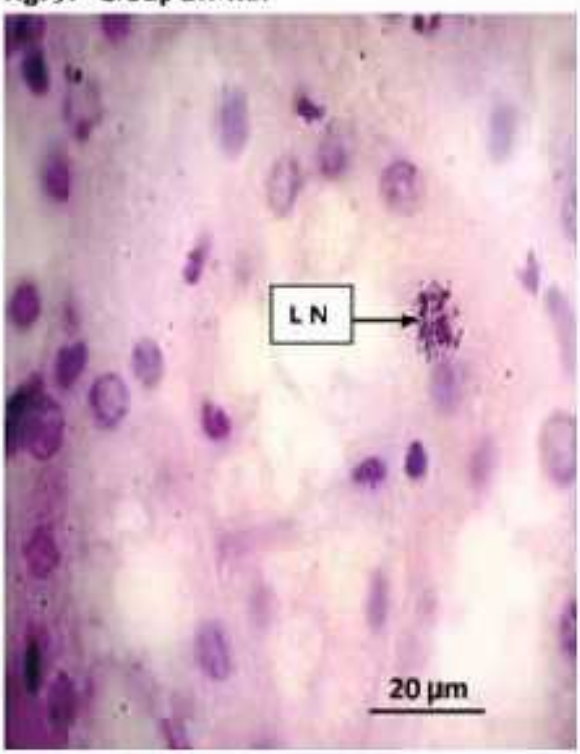

Figs. $(7,8,9)$ : Autoradiograms of ' $\mathrm{H}$-thymidine labelled kidrey stained with $\mathrm{H} 8 \mathrm{EE}$. showing the distribution of labeled nuctet (UN) in cortical portion of rend tubules of male mice after long term exposure, 7 . Control mica (C). 8- Exposed to a single dose of DMBA for 120 days (DN) and 9-Exposed to a single dose of DMBA for 120 days and $t \mathrm{~b}$ a daily injection of melatonin for last 30 days $\left(D_{A}+M_{A}\right)$.

Fig 10: Group a

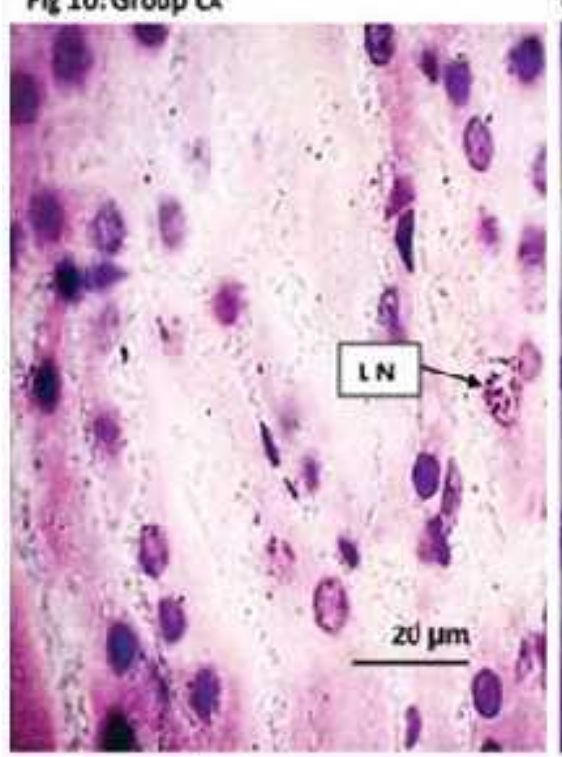

Fig 11: Group DA
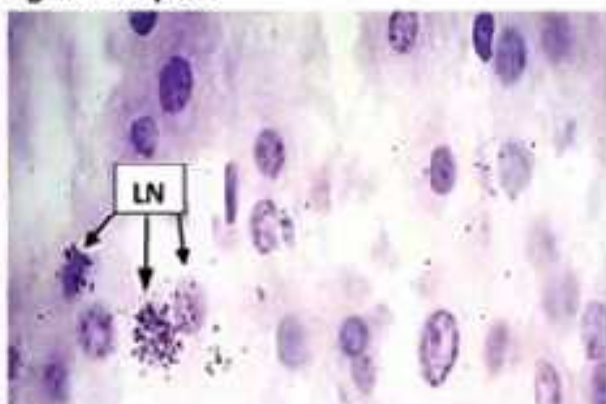

Fig 12: Group DA+MA

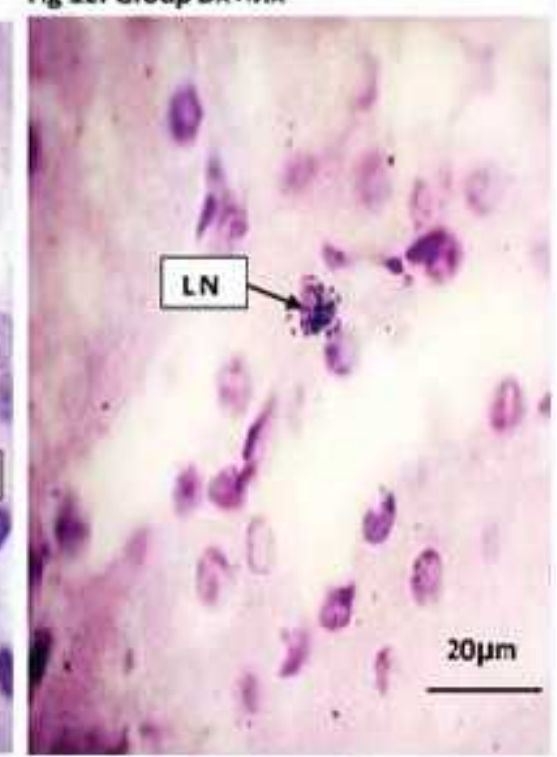

Figs. (10,11,12): Autoradiograms of ${ }^{3} \mathrm{H}$-thymidine labeled kidney stained with $\mathrm{H} \& \mathrm{E}$. showing the distribution of labelled nucle (LN) in meduliary portion of renal tubules of male mice after long term exposure. 10-contro mise $\left(C_{N}\right)$, 11-Expcsed to a single dose of DMBA for 120 days $\left(D_{A}\right)$ and 12 Exposed to a single dose of UMBA for 120 days and to a dally injection of melatcrin for last 30 days 
Table 3: ${ }^{3} \mathrm{H}$-labelling indices and grain counts/labelled nucleus in cortical and medullary portions of renal tubules of female mice after short term exposure. $\mathrm{C}=$ control, $\quad \mathrm{D}=$ single dose injection of DMBA; $\mathrm{D}+\mathrm{M}=$ single dose injection of DMBA and daily injection of melatonin

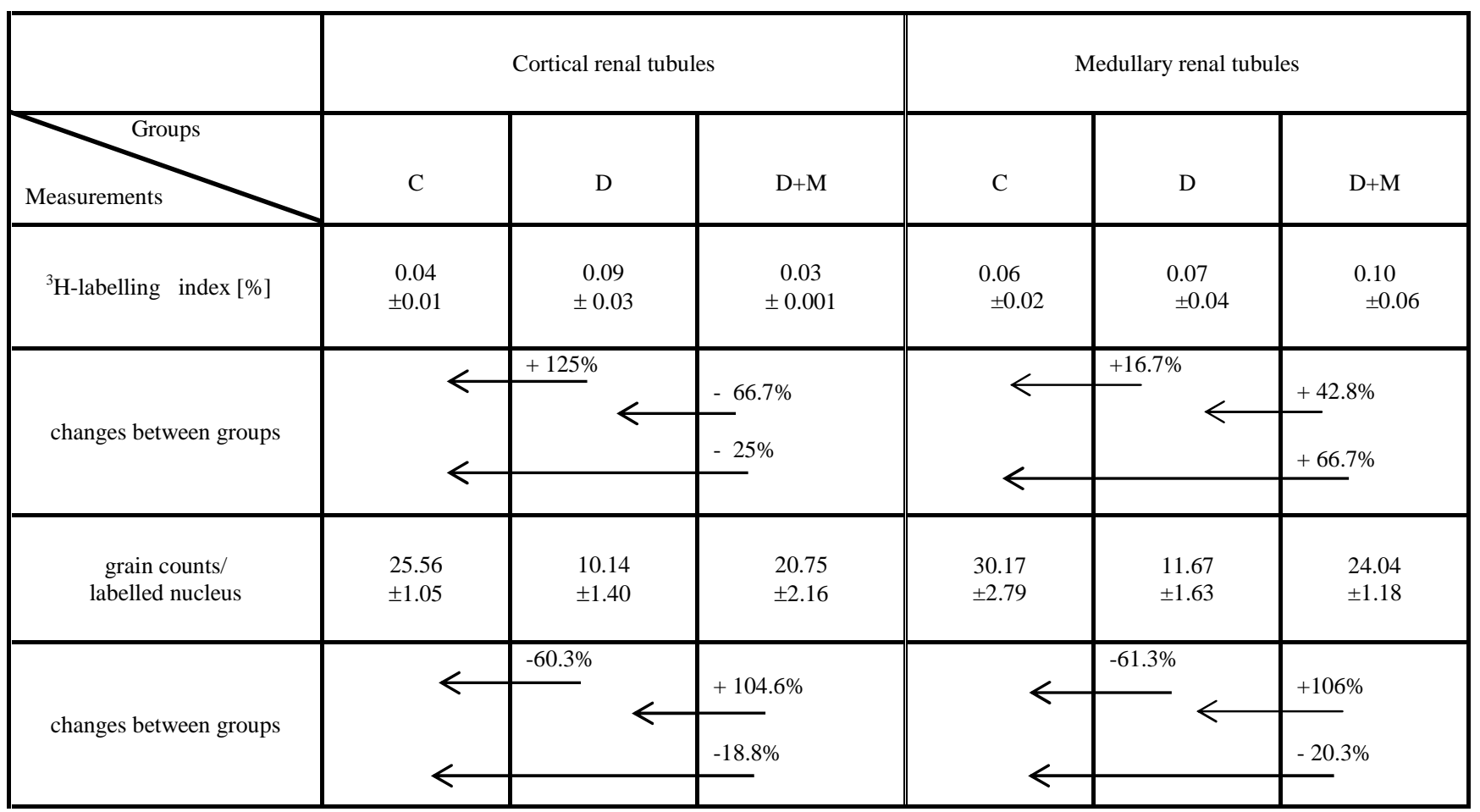

Data are given as mean $\pm \mathrm{SE}$;

Table 4: ${ }^{3} \mathrm{H}$-labelling indices and grain counts/labelled nucleus in cortical and medullary portions of renal tubules of female mice after long term exposure (120 days); $C_{A}=$ control, $\quad D_{A}=$ single dose injection of DMBA $D_{A}+M_{A}=$ single dose injection of DMBA and daily injection of melatonin.

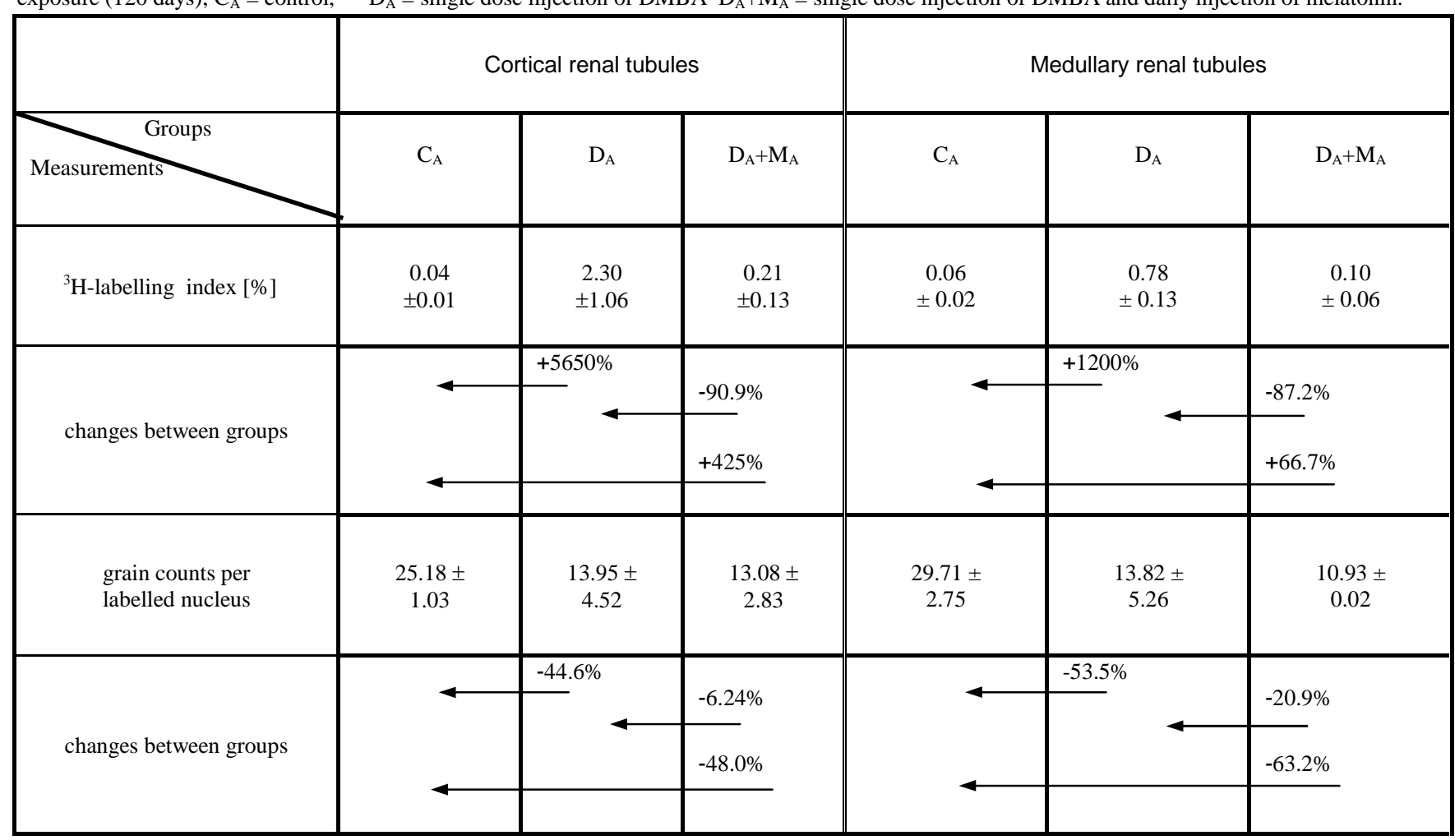

Data are given as mean $\pm \mathrm{SE}$; 


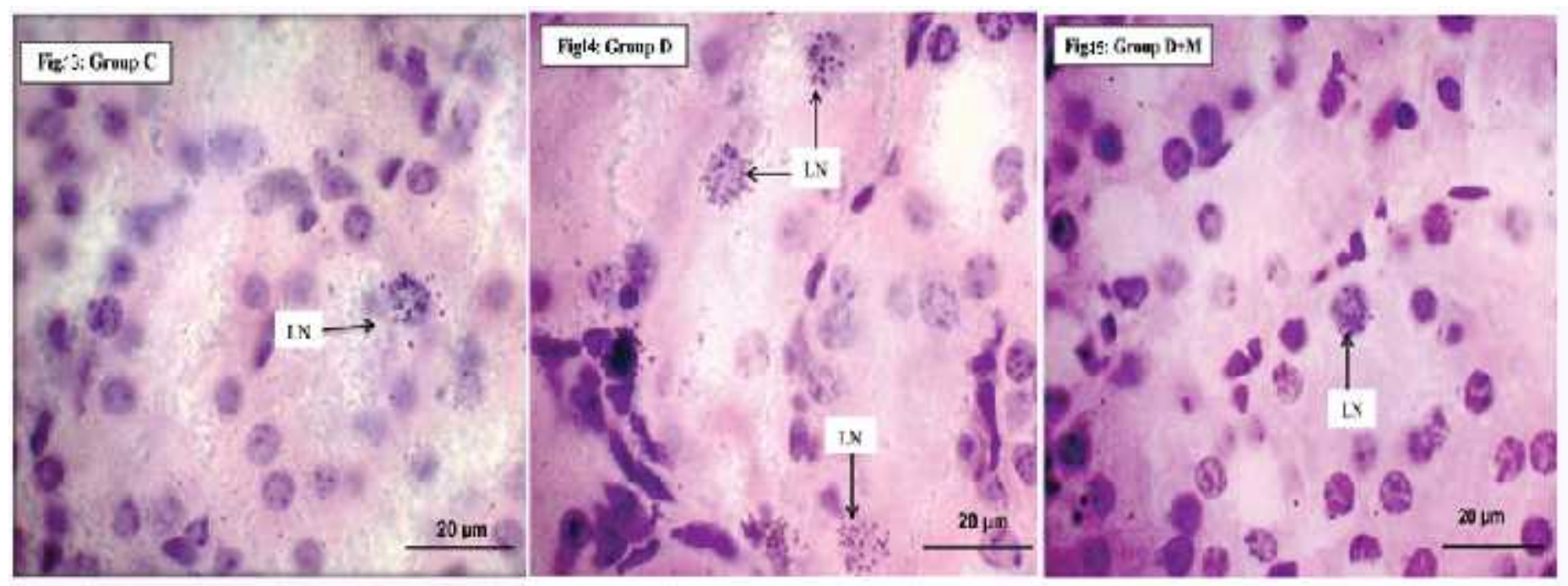

Figs. 113.14 15 :Autoradiograms of ${ }^{3} \mathrm{H}$.thymidine labelled kidney stained with H\&E. showing the distribution of radiolabelled nuclei (LN) in cortical partion of renal fubules of female mice after short term exposure. 1k* Control mice (C), 14. Exposed to a single dose of DMBA for 61 days (D) and15. Exposed to a single dose of DMBA for 61 days and to a daily injoction of melatonin for 60 days (D+M)

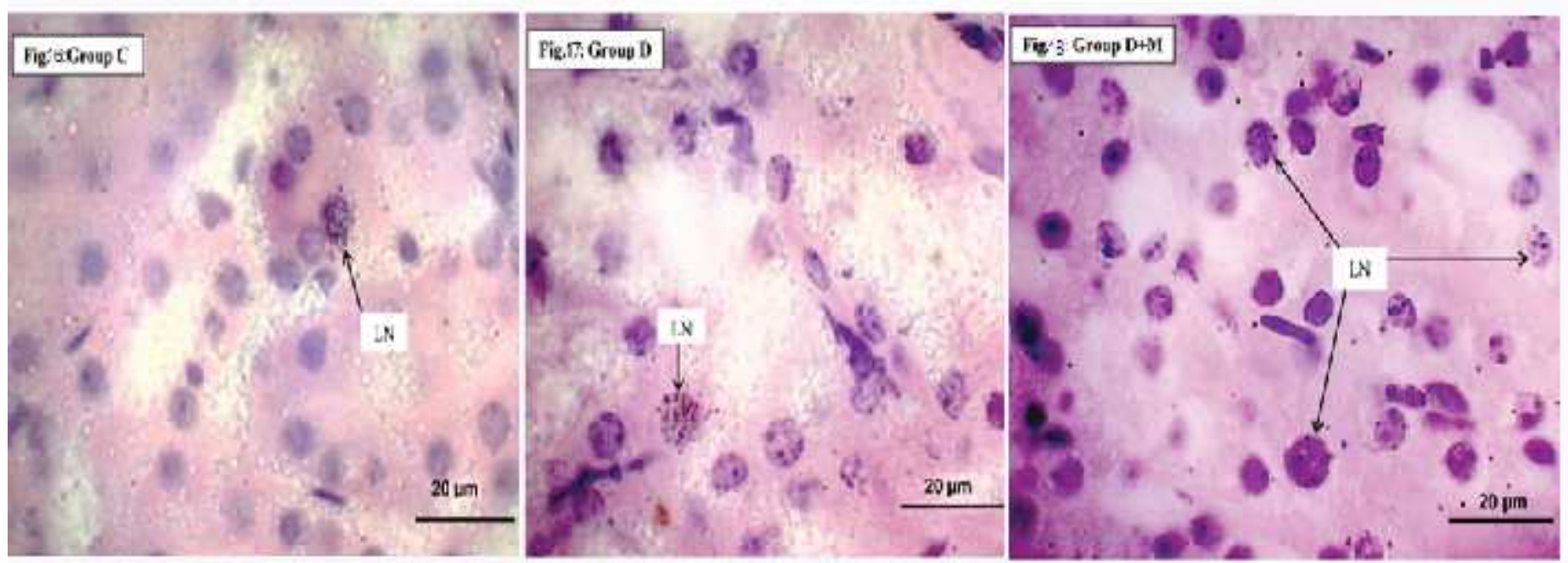

Figs. fintzig):Autoradiograms of 'Hattymidine labelled kidney stained with H\&E showing the distnbution of radiolabelled nuclei (L.N) in medullary portion of senal tubules of temale mice atter short term exposure. 16. Control mice (C), Tr. Exposed to a single dose of DMBA for 61 days (O) and "A. Exposed to a single dose of OMBA for 61 days and to a daily injection of melatonin for 60 days $(\mathrm{D}+\mathrm{M})$. 

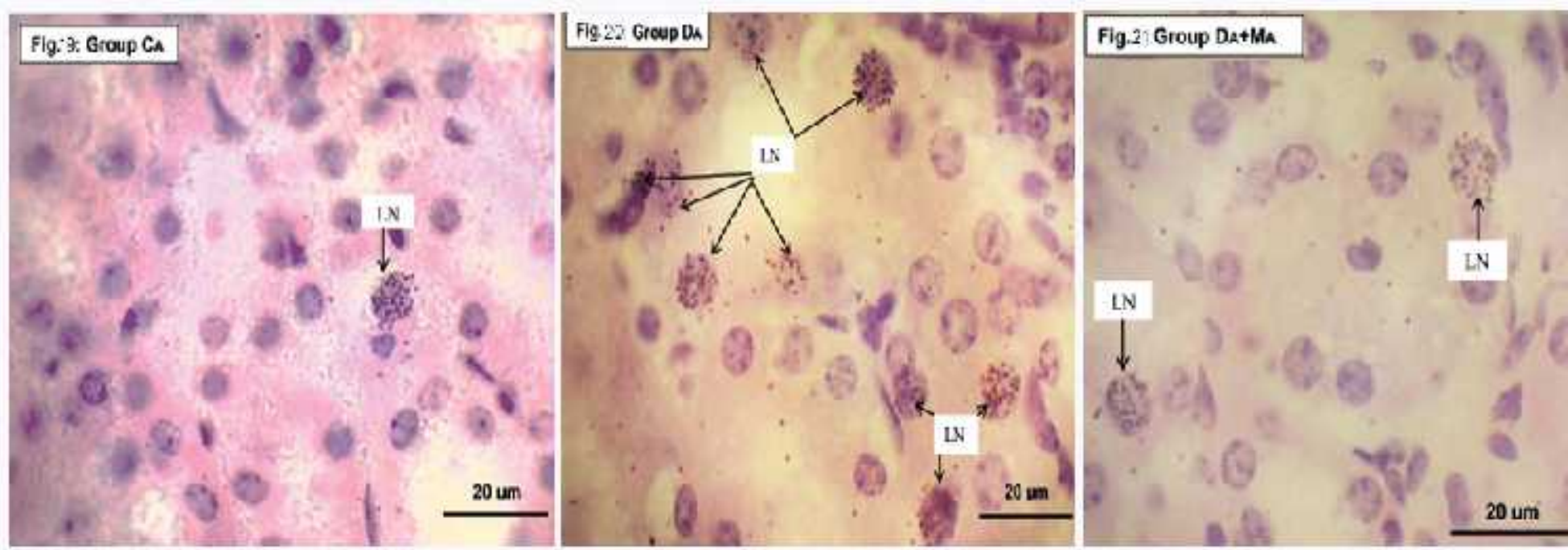

Figs (1923,41):Autoradiograms of 'H-thymidine labelled kidney stained with H\&E. shawing the diatribution of radiolabelled nuclei (LN) in cortical portion of renal tubules of fernale mice alter kong term exposure, 19. Control mice $\left(C_{N}\right), 20$. Exposed to a single dose of DMBA for 120 days (D, ) and 21-Exposed to a single dose of DMEA for 120 to a dally injoction of melatonin for last 30 days $\left(D_{n}+\mathrm{MN}\right)$.

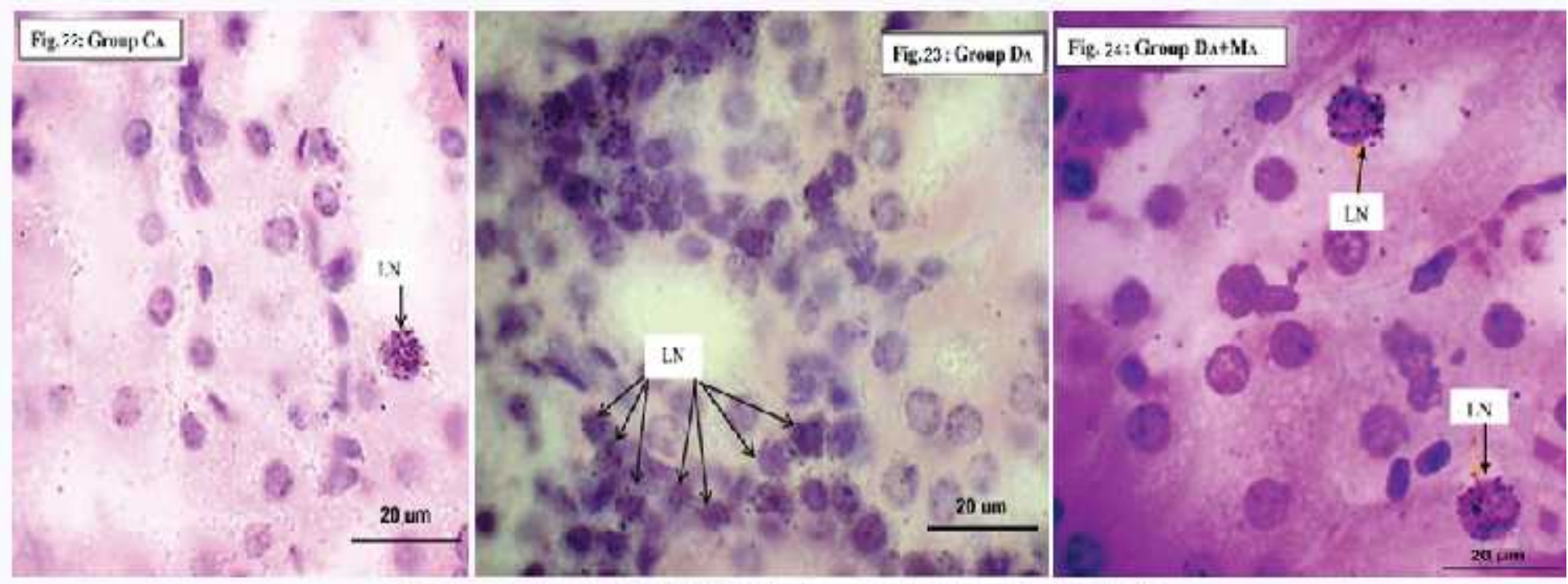

Figs. $(22,23,44)$ : Autoradiograms of ${ }^{5} \mathrm{H}$-thymicine labelled kidney stained with H\&E. showing the distribution of radiolabelled nuclei $(L N)$ in medullary portion of renal tubules of female mice after long term exposure 22 -control mice $\left(C_{h}\right), 23$ - Exposed to a single dose of DMBA for 120 days (D) and 24- Exposed to a single dose of DMBA for 120 days and to a daly injection of melatonin for last 30 days $\left(D_{n}+M_{N}\right)$. 
Taking these observations into consideration, the changes in the proliferation rate of cells detected in the present study are somewhat reasonable.

Administration of DMBA affected also DNA synthesis. After short term exposure to PAH the mean grain count over labelled nuclei dropped in both portions of the examined renal tubules. After long term exposure, DNA synthesis in the cortical part of tubules remained within the range of control, while it increased in the medullary portion. Such differences might be partly explained as inter-individual variations in levels of expression and catalytic activities of a variety of enzymes that activate and/or detoxify PAHs. These phenomena are thought to be critical in understanding the basis of individual differences in response to PAHs. Factors affecting such variations include induction and inhibition of enzymes by diverse chemicals and, more importantly, genetic polymorphisms of enzymes in humans (Shimada, 2006).

Such variations in DNA synthesis observed in the present study are in agreement with published data and various experimental settings. Injection of lead acetate induced characteristic temporal changes in DNA synthesis in the kidney of mice as determined by autoradiography and by assays of specific activity of DNA. Initially, there was a quiescent period followed by a burst of DNA synthesis (Choie and Richter, 1972; 1974; Gordon, 1975).

In the present study, daily injection of melatonin $(100 \mu \mathrm{g} /$ $100 \mathrm{~g}$ b.w.) after administration of DMBA reduced the incorporation of ${ }^{3} \mathrm{Hthymidine}$ into the cell nuclei in both short and long terms. Although the experimental settings were significantly different, the labelling index of nuclei was reduced by nearly identical percentages in both experimental settings compared to group C. It could be concluded that neither the onset point of melatonin application nor the duration of the treatment could influence the attenuating effect on cell proliferation significantly.

The pineal hormone melatonin affects a range of various processes such as cell growth, metabolic activity and cell cycle distribution (Natarajan et al., 2001). It proliferative as well as antiproliferative properties as documented in several normal and tumoraltissues of various organs (Sáinz et al., 1998;Zhao et al, 2002; El-Sokkary, 2002; 2007). This effect seems to be age dependent. In old rats (25 month old), melatonin administration increased the proliferative activity and the rate of DNA synthesis in lymphocytes of both the spleen and thymus (El-Sokkary et al., 2003).

The cell proliferative effect of melatonin seems to be affected at various levels and in different ways. It inhibits the expression of cellular genes associated with cell cycle progression, cell growth and differentiation, e.g.by regulating the key transcriptional regulator nuclear factorkappa B (Natarajan et al., 2001). Its antiproliferative effect seemsalso to be mediated through $\mathrm{mt}(1)$ Receptor-mediated events (Zhao et al, 2002) or by decrease of mRNA for the histone H4 (Sáinz et al.,1998).
An additional metabolic effect of melatonin is its influence on oxidative stress. Melatonin protects against and reduces oxidative stress induced by various xenobiotics (Nava et al., 2000; Granzotto et al., 2001; El-Sokkary, 2007). In the kidney of mercuric chloride intoxicated rats, the pineal hormone attenuates acute renal failure through a pertussis toxin-sensitive adenylatecyclase coupled G(i)-protein (Nava et al., 2000). In phenobarbital-treated rats melatonin reduced significantly $(\mathrm{P}<0.01)$ the lipid peroxidation levels $(23.5 \%)$, labelling index $(38.2 \%)$ and rate of DNA synthesis $(29.0 \%)$, and increased the cell cycle time (ElSokkary, (2007).

During the last decade, it has been demonstrated that melatonin influences beside the activity of antioxidant enzymes also genomic factors and thus regulates the expression of several genes, such as cellular mRNA levels for these enzymes (Rodriguez et al., 2004).Furthermore, melatonin is able to inhibit programmed cell death in thymus, in vivo and in vitro (Sáinz et al., 1998) and in cancer cells (Rodriguez et al., 2013). The pineal hormone reduces also vascular endothelial growth factor (VEGF) secretion and controls thereby the neoplastic growth in advanced cancer. Thereby it may control tumor growth at least in part by acting as a natural anti-angiogenic molecule, with a following opposition or angiogenesisdependent cancer proliferation (Lissoni et al., 2001).

\section{Conclusion}

Melatonin provides a beneficial effect on DMBA induced changes in cell proliferation and DNA synthesis as it affects a range of various physiological processes such as cell growth, metabolic activity, and cell cycle distribution. Its antiproliferating effect seems neither be influenced by the onset point of indole application nor duration of treatment.

\section{References}

Agrawal. A., Verma. P. and Goyal, P.K. (2010).

Chemomodulatory effects of Aegle marmelos against DMBA-induced skin tumorigenesis in swiss albino mice. Asian Pac. J. Cancer Prev., 11:131-139.

Baird, W.M., Hooven, L.A. and Mahadevan, B. (2005). Carcinogenic polycyclic aromatic hydrocarbonDNA adducts and mechanism of action. Environ. Mol. Mutagen., 45:106-114.

Bishayee, A., Oinam, S., Basu, M. and Chatterjee M. (2000). Vanadium chemoprevention of 7, 12-dimethylbenz (a) anthracene-induced rat mammary carcinogenesis: probable involvement of representative hepatic phase I and II xenobiotic metabolizing enzymes. Breast Cancer Res. Treat., 63(2):133-145.

Batcioglu, K., Karagozler, A.A., Ozturk, I.C., Genc, M., Bay, A., Ozturk, F. and Aydogdu N. (2004). Comparison of chemopreventive effect of Vitamin E pus selenium versus melatonin in 7 , 12dimethylbenz[a]anthracene-induced mouse brain damage. Cancer Detect. Prevent., 29:54-58.

Bisht, S., Feldmann, G., Soni, S., Ravi, R., Karikar, C., Maitra, Am. and Maitra, An. (2007). Polymeric 
nanoparticle-encapsulated curcumin (nanocurcumin): a novel strategy for human cancer therapy. J. Nanobiotechnol., 5:3.

Cazzaniga, M. and Bonanni, B. (2012). Breast cancer chemoprevention: old and new approaches. J. Biomed. Biotechnol., 2012:1-15.

Chinchali, J.F., Sanakal, R.D. and Kaliwal, B.B. (2011). Evaluation of anticarcinogenic activity of Clerodendrum serratum leaf extract on liver and kidney of 7, 12 dimethylbenz[a]anthracene (DMBA) induced skin carcinogenesis in mice. Euro. J. Exp. Biol., 1(4):130-141.

Currier, N., Solomon, S.E., Demicco, E.G., Chang, D.L., Farago, M., Ying, H., Dominguez, I., Sonenshein, G.E., Cardiff, R.D., Xiao, Z.X., Sherr, D.H. and Seldin, D.C. (2005). Oncogenic signaling pathways activated in DMBA-induced mouse mammary tumors. Toxicol. Pathol., 33(6):726-737.

Das, B.N., Biswas, B.K., Moghal, M.M.R., Basher, M.A. and Ahmed, M. (2010). Study of analgesic activity of bark of Xeromphis spinosa. Int. J. Compr. Pharm. Pharm. Glob., 1(2):1-3.

Ebeed, N.M., Abdou, H.S., Booles, H.F., Salah, S.H., Ahmed, E.S. and Fahmy, K.H. (2010). Antimutagenic and chemoprevention potentialities of sweet fennel

(Foeniculum vulgare Mill.) hot water crude extract. J. Am. Sci., 6:831-842.

El-Bakry, H.A., Abd-Elghany, M.I. and Soliman, S.S. (2014). Role of the Pineal Gland in DMBA-Induced Hematotoxicity, Immunotoxicity and Mammary Carcinogenesis. Acad. J. Cancer Res., 7 (2): 81-97.

El-Sokkary, G.H., Reiter, R.J. and Abdel-Ghaffar, S.K.H. (2003). Melatonin supplementation restores cellular proliferation and DNA synthesis in the splenic and thymic lymphocytes of old rats. Neuro. Endocrinol. Lett., 24: 215 223.

Feng, L., Jia, X., Zhu, M., Chen, Y. and Shi, F. (2010). Chemoprevention by Prunella vulgaris L. extract of nonsmall cell lung cancer via promoting apoptosis and regulating the cell cycle. Asian Pac. J. Cancer Prev., 11:1355-1358.

Ferreira, G.M., Martinez, M. and Camargo, I.C.C., Domeniconi, R.F., Martinez, F.E. and Chuffa, L.G.A. (2014). Melatonin attenuates Her-2, p38 MAPK, p-AKT, and mTOR levels in ovarian carcinoma of ethanolpreferring rats. J. Cancer, 5(9):728-735.

Huggins, C., Grand, L.C. and Brillantes, F.P. (1961). Mammary Cancer Induced by a Single Feeding of Polynuclear Hydrocarbons, and its Suppression. Nature, 189: 204-207.

Jayaraj. F. Chinchali, Rajeshwari. D. Sanakal and Basappa. B. Kaliwal. (2011). Evaluation of
anticarcinogenic activity of Clerodendrum serratum leaf extract on liver and kidney of 7, 12dimethylbenz[a]anthracene (DMBA) induced skin carcinogenesis in mice. Eur J Exp Biol, 2011, 1 (4):130141.

Lin, Y., Yao, Y., Liu, S., Wang, L., Moorthy, B., Xion, D., Cheng, T., Ding, X. and Gu, J. (2012). Role of mammary epithelial and stromal P450 enzymes in the clearance and metabolic activation of 7,12 dimethylbenz(a)anthracene in mice. Toxicol. Lett., 212(2): 97-105

Manoharan, S. and Selvan M.V. (2012). Chemopreventive potential of geraniol in 7, 12dimethylbenz(a)anthracene (DMBA) induced skin carcinogenesis in Swiss albino mice. J. Environ. Biol., 33:255-260.

Marnett, L.J., Riggings, J. N. and West, J.D. (2003). Endogenous generation of reactive oxidants and electrophiles and their reactions with DNA and protein. J. Clin. Invest., 111: 583-593.

Mian-Ying, W., Peng, L., Anderson, G., Nowicki, D. (2013). Breast cancer prevention with Morinda citrifolia (noni) at the initiation stage. Funct. Foods Health Dis., 3(6):203-222.

Mirunalini, S., Karthishwaran, K., Dhamodharan, G. and Shalini, M. (2010). Studies on the chemopreventive potential of melatonin on 7, 12-dimethylbenz(a)-anthracene induced mammary carcinogenesis in rats. J. Appl. Sci. Res., 6(3): 245-253.

Phillips, T.L. and Leong, G.F. (1967). Kidney cell proliferation after unilateral nephrectomy as related to age. Cancer Res., 27, 286-292.

Qing, J., Maher, V.M.,Tran, H., Argraves, W.S., Dunstan, R.W. and McCormick, J.J. (1997). Suppression of anchorage-independent growth and matrigel inva-sion and delayed tumor formation by elevated expression of fibulin$1 \mathrm{D}$ in human fibrosarcoma-derived cell lines. Oncogene, 15:2159-2168.

Reiter, R.J., Mc Creight, C.E. and Sulkin, N.M. (1964). Age differences in cellular proliferation in rat kidneys. J. Gerontol., 19: 485-493.

Sharma, V. and Paliwal, R. (2014). Potential chemoprevention of 7,12 dimethylbenz[a]anthracene induced renal carcinogenesis by Moringa oleifera pods and its isolated saponin. Indian. J. Clin. Biochem., 29(2):202909.

Sharma, V., Paliwal, R., Janmeda, P. and Sharma, S.H. (2012). Chemopreventive efficacy of Moringa oleifera pods against 7,12-dimethylbenz[a]anthracene induced hepatic carcinogenesis in mice. Asian Pac. J. Cancer Prev., 13:2563-2569.

Shimada, T. and Fujii-Kuriyama, Y. (2004). Metabolic activation of polycyclic aromatic hydrocarbons to carcinogens by cytochromes P450 1A1 and 1B1. Cancer Sci., 95(1):1-6.

Wang, M.Y., Peng, L., Anderson, G. and Nowicki, D. (2013). Breast cancer prevention with Morinda citrifolia (noni) at the initiation stage. Functional Foods in Health Dis., 3(6):203-222. 